\title{
$\begin{array}{llllllllllllllllllllll}\text { E } & \mathrm{S} & \mathrm{R} & \mathrm{C} & & \mathrm{C} & \mathrm{E} & \mathrm{N} & \mathrm{T} & \mathrm{R} & \mathrm{E}\end{array}$ \\ $\begin{array}{llllllllllllllll}S & K & I & L & L & S & & K & N & O & W & L & E & D & G & E\end{array}$ $\begin{array}{llllllllllllllllll}A & \mathbf{N} & \mathbf{D} & \mathbf{O} & \mathbf{R} & \mathbf{G} & \mathbf{A} & \mathbf{N} & \mathbf{I} & \mathbf{S} & \mathbf{A} & \mathbf{T} & \mathbf{I} & \mathbf{O} & \mathbf{N} & \mathbf{A} & \mathbf{L}\end{array}$ $\begin{array}{lllllllllll}\mathbf{P} & \mathbf{E} & \mathbf{R} & \mathbf{F} & \mathbf{O} & \mathbf{R} & \mathbf{M} & \mathbf{A} & \mathbf{N} & \mathbf{C} & \mathbf{E}\end{array}$
}

\section{Corporate Ownership and Initial Training in Britain, Germany and Switzerland}

SKOPE Research Paper No. 99 December 2010

\author{
Paul Ryan*, Karin Wagner**, Silvia Teuber***, Uschi Backes-Gellner*** \\ * King's College Cambridge \\ ** Hochschule für Technik und Wirtschaft Berlin \\ *** University of Zurich
}
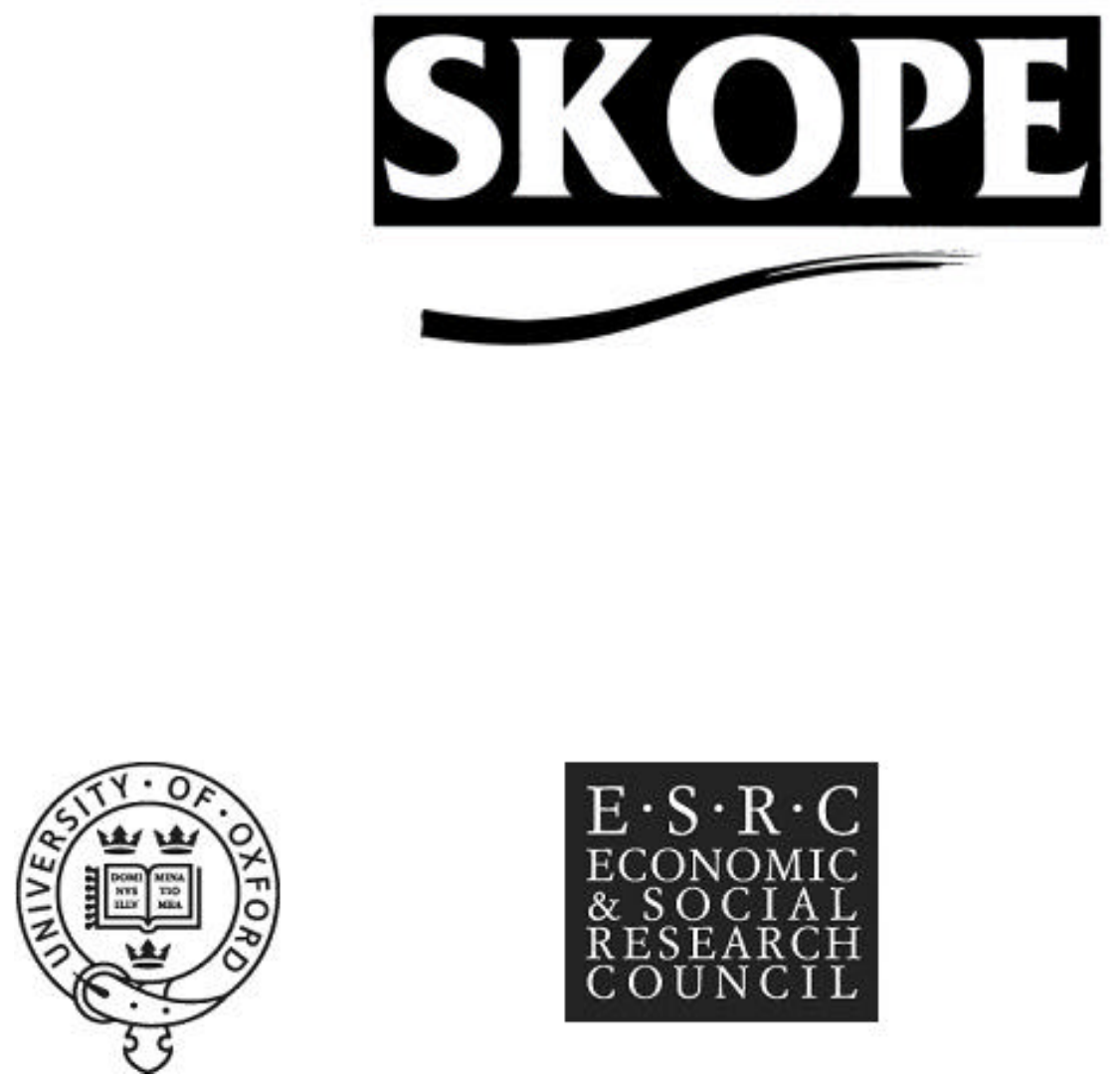



\section{Editor's Foreword}

\section{SKOPE Publications}

This series publishes the work of the members and associates of SKOPE. A formal editorial process ensures that standards of quality and objectivity are maintained.

Orders for publications should be addressed to the SKOPE Secretary, School of Social Sciences, Cardiff University, Glamorgan Building, King Edward VII Avenue, Cardiff CF10 3WT

Research papers can be downloaded from the website: www.skope.ox.ac.uk

ISSN 1466-1535

(C) 2010 SKOPE 



\begin{abstract}
This paper considers whether listed companies with dispersed ownership invest less in training than do other firms, as part of a short-termist stance caused by pressure from the stock market. An analytical framework that supports the proposition involves three factors: high agency costs between the shareholders and managers of listed firms that have dispersed ownership; the use of highly geared performance-related pay to reward top managers; and accounting conventions that distort performance measures by requiring that spending on intangible assets be expensed not amortised. Managers then have the incentive and ability to restrict spending on training in order to increase their remuneration. Countervailing factors, including institutions of corporate governance, may however weaken or destroy such effects. Evidence is presented concerning the initial training programmes of 56 companies in engineering and retailing in Britain, Germany and Switzerland. The evidence is consistent with ownership effects in both sectors, but those effects are at most moderate in both incidence and strength. The skill requirements of competitive success in product markets appear more important than ownership.
\end{abstract}





\section{Introduction}

The possibility that a company's finance and ownership affect its decisions concerning skills and training has been extensively discussed by institutionallyoriented social scientists. 'Shareholder' firms are contrasted to 'stakeholder' ones, in terms of their orientation to the interests of shareholders as opposed to those of employees, customers, and suppliers. ${ }^{1}$ In the related dichotomy between 'AngloSaxon' and continental European ways of organising business, national systems of corporate ownership, finance and governance, on the one side, and skill development, on the other, differ between 'liberal' and 'coordinated' market economies. ${ }^{2}$

Shareholder-oriented firms may invest less in employee skills than do stakeholder-oriented ones as part of a short-termism caused by their greater exposure to the stock market. Evidence that the stock market pressures associated with dispersed ownership have economic drawbacks comes from the positive association between the leading form of ownership concentration - family control - and profitability among large listed firms in the US - although the contribution of family control to productivity depends on the employment of non-family members as managers. $^{3}$

Several mechanisms potentially link dispersed ownership to training. First, inefficiently high discount rates may be required in order to raise external equity, penalising long-term investment projects in general, and costly training programmes in particular. ${ }^{4}$ Second, the use of performance-related pay to reward corporate managers may reduce longer-term investment by encouraging them to spend less, in order to change reported earnings to their own advantage. The problem potentially focuses on listed companies with dispersed ownership, in which agency problems between shareholders and managers are expected to be most severe, and in which the accounting scandals of the early 2000 s were concentrated. ${ }^{5}$ Finally, accounting conventions, which require that spending on intangible assets be fully expensed rather than amortised, may prevent companies from showing the stock market the benefits of

\footnotetext{
${ }^{1}$ E.g. Armour et al (2003), Solomon (2010).

${ }^{2}$ E.g. Mayer (1997), Porter (1998), Hall and Soskice (2001).

${ }^{3}$ Anderson and Reeb (2003), Bloom and van Reenen (2007).

${ }^{4}$ Miles (1995).

${ }^{5}$ Healy and Wahlen (1999), Coffee (2005).
} 
such spending, which includes training alongside R\&D and advertising. ${ }^{6}$ The combined effect of these factors is likely to be particularly marked when the training in question is potentially expensive to the employer, as in the case of apprenticeship training for highly skilled occupations.

There is considerable evidence on these three factors, but their interaction and combined effect on training remain unclear. Data that cover simultaneously both ownership and training across plants and companies are not readily available. This paper uses fieldwork for insights into these issues. Evidence is taken primarily from interviews with senior managers in 56 establishments in two sectors - engineering and retailing - in three countries - Britain, Germany and Switzerland - part of a wider project whose primary concern is pay structure and training. These three countries were chosen because of differences in national training methods, institutions of pay setting, and corporate ownership, as well as differing national expertise within the research team. Engineering and retailing were chosen as representing opposite poles in the national distributions of skill requirements and training methods. ${ }^{7}$

Establishments were selected, where possible, to match them by product line, while differentiating them by corporate ownership and finance. Evidence was found consistent with selective ownership effects on training volume within engineering, along with cases in which financial upheaval has led a company to reduce training. These effects are however not widespread, and most interviewees see product market competition as a more powerful influence on their training decisions than are ownership and finance - as might indeed be expected from an economic standpoint.

Section two discusses the potential association between corporate finance and initial training, including evidence from the US. The attributes of corporate ownership and initial training in the three countries are presented in section three. Section four outlines the data and research methods. Section five analyses our evidence and the conclusions follow in section six.

\section{Corporate ownership and training}

Why might one company be expected to invest less in training than an otherwise similar company because of differences in their ownership and finance? The answer potentially involves three factors: agency costs between owners and managers,

\footnotetext{
${ }^{6}$ Green et al (1996), Konzelmann et al (2006).

${ }^{7}$ Ryan et al (2010).
} 
performance-related pay for managers, and accounting conventions. A simplified statement of the hypothesis is that the owners of firms with a stock market listing and dispersed ownership typically use performance-based bonuses to reward top managers, and that accounting practices mean that these bonus systems perversely encourage managers to restrict spending on training in order to increase their own bonuses. This section discusses these factors with reference to the extensive evidence available for the US.

The three factors taken together provide a particular explanation of 'shorttermism' - i.e. willingness to sacrifice longer-term benefit for short-term advantage when it is economically inefficient to do so. Some analyses of short-termism apply to corporate investment as a whole: e.g. the view of stock markets as systematically discounting a company's future revenues at a higher rate than is warranted by the general cost of capital and a sector-specific risk premium. ${ }^{8}$ If that kind of shorttermism is present, all long-term investment, in fixed assets as well as intangibles, is sub-optimal. This paper's analysis of short-termism is more narrowly focused. It applies specifically to investment in intangible assets by listed companies with dispersed ownership.

\section{Agency costs and ownership structure}

The starting point is the classic principalagent problem between the owners and managers of large businesses. Listed firms with dispersed ownership involve conflicts of interest between owners (shareholders) and managers, as part of the divorce between ownership and control. Owners are assumed to want the firm to maximise profits (shareholder value); managers, to maximise their own utility, which is assumed to be the same as their income. The two parties' goals potentially conflict: e.g. if pay increases with the size of the firm, managers have an incentive to make acquisitions that increase sales, even when making a takeover can be expected to reduce profits. Assuming asymmetric information, owners are unable to observe managers' choices of action, which gives managers scope to pursue their own goals rather than those of owners.

Managers might still be induced to pursue owners' interests by the external monitoring of their decisions. The task could in principle be performed directly by owners themselves. In unlisted companies and closely held listed ones, the dominant

\footnotetext{
${ }^{8}$ Miles (1995).
} 
or sole owner has both the incentive and the position to do the monitoring. However, when there are many owners, none of them has much incentive to monitor managers' decisions, as only a small share of the benefits will accrue to the one who bears the cost.

The task of monitoring managers in the interest of shareholders belongs formally to the board of directors. Managers are however often seen to dominate the board, in terms of membership, agenda, and information. A second potential curb on managerial independence is the market for corporate control. Managers who pursue their own interests at the expense of owners risk provoking a hostile takeover bid, with their employment and perks at risk if it succeeds. They may though be able to deter hostile bids, by using special share issues, poison pills and the like. In practice, if neither the board of directors nor the takeover threat provides a serious constraint, given asymmetric information, listed companies with dispersed ownership are expected to exhibit managerial entrenchment. ${ }^{9}$

\section{Management remuneration}

In such cases, a further option for reducing goal divergence between owners and managers under dispersed ownership is performance-related pay: tying managers' remuneration to one or more indicators of their success in promoting owners' interests. When bonuses are geared sufficiently strongly to the firm's performance, self-interest should induce managers to try to maximise performance. The potential performance indicators are both accounting-based (reported profits) and market-based (share price).

In large US companies, managers typically have complex remuneration packages, comprising base pay, bonuses depending on short-term (current year) and medium-term (three to five year) reported profits (e.g. earnings per share, return on capital), and stock options, whose value depends on the firm's share price. In the 1990s, stock options came to dominate the remuneration of chief executives. ${ }^{10}$ The

\footnotetext{
${ }^{9}$ Concerns about conflicts of interest in closely held companies focus on those between the dominant owner and minority shareholders, which carry no direct implications for skills and training (Morcket al 2005, Enriques and Volpin 2007).

${ }^{10}$ Bebchuk and Grinstein (2005). The share of stock options in the total remuneration of top executives in the US rose from one per cent in 1984 to around two-thirds in the bubble economy of 2001 (Coffee 2005: Figure 2).
} 
gearing of bonuses and options to performance indicators, particularly the firm's share price, is particularly strong in dispersed ownership firms. ${ }^{11}$

The performance criteria used in management bonus systems focus mostly on short-term indicators, such as reported earnings per share in the current year and the share price at the end of the year. To that extent, managers are incentivised to increase short-term performance even when that comes at the expense of long-term performance. $^{12}$

\section{Accounting conventions}

The third factor is the scope given by accounting practices to top managers to manipulate reported profits, and to raise the company's share price, so as to increase their pay. The issue is that 'generally accepted accounting principles ... do not always reflect firm value on a timely basis'. ${ }^{13}$

Earnings may be managed along two routes. The first is the treatment of accruals in the firm's profit and loss statement, i.e. the adjustment of cash flow to allow for the non-instantaneous depreciation of assets, the value of contracts for future sales, etc. By booking anticipated revenues early and current expenses late, given cash flow, managers can increase reported profits in the current accounting period. Accruals-based earnings management, long prominent, became widespread among listed companies in the US during the early 2000s. In the extreme cases, which became household names, notably Enron, WorldCom and Tyco, it led to bankruptcy and prosecution for securities fraud. ${ }^{14}$ It occurs more frequently and on a large scale in companies that gear bonus pay strongly to performance indicators in general, and those with high 'option sensitivity' in particular. ${ }^{15}$

The second type of earnings management is the manipulation of real activities, which alters reported profits by changing cash flows. ${ }^{16}$ The focus is spending on internally generated intangible assets, notably research and development, advertising,

\footnotetext{
11 Murphy (1999), Bebchuk and Grinstein (2005), Coffee (2005), Monks and Minow (2008: 310). Other components of remuneration include pension rights.

12 Jensen and Murphy (2004). Murphy (1999) notes that although top managers' pay depends more on the share price than on accounting profits, the dependence of the former on the latter encourages managers to focus their efforts on the latter.

${ }^{13}$ Dechow and Sloan (1991: 53).

${ }^{14}$ Healy (1985), Healy and Wahlen (1999). Accounting irregularities at WorldCom included the treatment of operating costs as investments, amortised across several years instead of expensed in full (Bergstresser and Philippon 2006).

${ }_{15}$ Bergstresser and Philippon (2006), Burns and Kedia (2006), Denis et al (2006), Chen et al (2010).

${ }^{16}$ Dechow and Sloan (1991), Roychowdury (2006).
} 
and employee training. Standard accounting conventions require companies to expense such spending fully on current account, i.e. treat it as an operating cost, rather than to amortise it, i.e. treat it as an investment on capital account, to be depreciated across more than one period and included as an asset in the balance sheet, as for spending on plant and equipment. The convention reflects a key attribute of intangibles: the difficulty of valuing the asset. Training involves exceptional measurement difficulty, given that the costs of on-the-job training are difficult to separate from those of production. There is also the absence of unambiguous ownership by the company of the resulting asset, which remains, de jure at least, the property of the employee, and which the company would therefore have write off were spending on it capitalised and were the employee to quit. ${ }^{17}$

These accounting conventions mean that, other things constant, a company that cuts spending on intangible assets reports higher profits in the same accounting period without changing its balance sheet substantially. Managerial remuneration then rises along three routes. First, higher reported earnings increase short-term bonuses. Second, to the extent that external investors rely on current accounting profits to value companies, the firm's share price rises, and with it the value of managers' stock options, which, if vested, can be sold at an inflated price. Third, the probability of hostile takeover, leading to job loss for top managers, falls. Managers can therefore gain by holding down spending on intangibles, particularly those with low external visibility, including training. ${ }^{18}$

Evidence on the manipulation of real activities mostly concerns R\&D, spending on which is relatively easy to measure and audit - for researchers and external investors alike. US listed companies who do $R \& D$ are seen to reduce spending in particular situations. One is a potential fall in earnings per share, e.g. as a result of the award of stock options to top managers themselves. Another is when a

\footnotetext{
${ }^{17}$ Roberts (2007). Recognition of intangibles as assets is generally confined to externally acquired ones, such as goodwill purchased in a takeover, and professional footballers purchased from another club (Benedict and Elliott 2008, Atrill and McLancy 2008). Proponents of 'human resource accounting', in advocating the capitalisation of spending on employee skills (Flamholtz 1999), implicitly give validity priority over reliability as criteria for choice of accounting practice.

18 According to one influential account of standard practice in American companies, '... important investments such as R\&D, advertising or market entry are often not treated as capital investments at all; rather they are negotiated as part of the annual budgeting process, which is driven by a concern for current profitability' and 'intangible investments such as training may not even be tracked by the financial system and fall prey to deferral in the name of increasing near-term profits' (Porter 1997: 11).
} 
chief executive with highly geared bonuses or large stock options is about to retire. ${ }^{19}$ Moreover, chief financial officers state candidly that they would and do change expenditure on real activities, notably $\mathrm{R} \& \mathrm{D}$, in order to increase current earnings, when that would allow the company to cross an earnings threshold, such as breaking even, even when doing so would mean 'burning economic value' (i.e. reducing future profits). ${ }^{20}$

\section{Interactions}

The interaction of payment systems and accounting conventions may therefore constrain spending on training in companies with dispersed ownership. The three factors are complements. Indeed, all must be present for the result to hold. When the agency problem is weak or absent, as in firms with a dominant owner, self-serving management decisions are more readily observed and blocked by the owner, and in any event, reported results are less central to owners' assessments of the firm's value and managers' performance. And when managers do not have access to high-powered bonus pay, there is less incentive to crank up reported profits in the first place.

The three factors may not however suffice to prevent economically beneficial spending on training. First, even when all three are present, the interests of top managers may not be uniformly short-termist. While a chief executive holding large stock options and approaching retirement has clear incentives to short-termism, others may be more interested in job security, and anticipate that an earnings restatement and damage to their careers will follow from any serious manipulation of earnings. ${ }^{21}$ Such managers may concentrate on smoothing fluctuations in reported earnings, e.g. by creating 'cookie jars' (concealed reserves). The tendency of stock markets to prize stability in reported performance encourages this kind of earnings management, which

\footnotetext{
${ }^{19}$ Bens et al (2003); Dechow and Sloan (1991). In the 1980s a high-tech company, Analytic Devices, spun off its R\&D into a separate company in order to avoid the effects of its high outlays on its share price - but did so only until changes in accounting standards removed that option (Stein 1989).

${ }^{20}$ Indeed, CFOs state that they prefer to manage earnings through real activities than through accruals, given that the former is not subject to intervention by the firm's auditors (Graham et al 2005). Other actions by which managers are seen to raise current reported profits include cutting product prices, producing surplus inventory, and deferring the maintenance of plant and equipment (Roychowdury 2006). There is also evidence of earnings management within multi-plant companies. Head offices typically give the managers of subsidiary units financial targets, and evaluate their performance in relation to those targets. Given that, subordinate managers tend to raise their bonuses by way of distorted inventory valuations, which are particularly difficult for head office to monitor (Guidry et al 1999).

${ }^{21}$ Coffee (2005), Burns and Kedia (2006).
} 
appears to predominate in block-holder and unlisted firms. ${ }^{22}$ Its implications for training may be more severe, however: longer-term restriction of spending replaces short-term restriction, given that benefit to top managers in the short-term of any temporary cut in training must be set against lower subsequent profits. ${ }^{23}$

Second, one or more of the three factors may be weak or absent, thereby shortcircuiting the incentive to managers to hold down spending on intangibles. Strong corporate governance and investor activism may enhance owners' monitoring of management decisions. ${ }^{24}$ Shareholder representatives may oppose the use of highly geared bonuses and stock options, in order to reduce short-termist side effects. Finally, external investors, including fund managers and analysts, have the incentive to look behind current financial statements to judge the company's value, thereby making the share price less sensitive to earnings manipulation. The last of these three constraints on managerial short-termism clearly matters in practice. Companies that spend highly on research and training have high ratios of market to book value. ${ }^{25}$ Companies' share prices typically increase when the firm announces increased spending on R\&D, even when that is accompanied by a fall in reported earnings. ${ }^{26}$

Moreover, contemporary changes in corporate law, regulation and practice have, in the US and the UK in particular, been aimed at all three aspects of managerial entrenchment in companies with dispersed ownership. Enhanced powers for boards of directors, along with increased autonomy from management, aim at improving owners' ability to monitor managers' decisions. The use of stock options to reward

\footnotetext{
${ }^{22}$ Leuz and Wüsterman (2004). See section 3, below.

${ }^{23}$ Fudenberg and Tirole (1995), Chung et al (2002). The relative importance of the two motives for earnings management is contested (Healy and Wahlen 1999). The two motives may be seen as partly substitutes, insofar as higher current earnings are obtained at the expense of lower future earnings, but also as partly complements, in the views of chief financial officers at least, who prefer a share price that is high as well as stable (Graham et al 2005).

${ }^{24}$ The effects on managerial short-termism of the long-term increase in the importance of institutional investors remains controversial. Some commentators see it as having increased short-termism, associated with high turnover in pursuit of rapid capital gains in the portfolios of many funds, particularly hedge funds, and with the willingness of fund managers to support hostile bids in failing companies rather than intervene to improve management, again in pursuit of near-term capital gains (Porter 1998, Jacoby 2009). Others see it as reducing short-termism, insofar as the increasing use of indexing strategies by investment funds, the growth of active investment funds, and the long-term horizons of pension funds in particular, encourage long-term holdings of particular companies' shares (e.g. Monks and Minow 2009). The former, pessimistic view is supported by evidence that companies that are formally charged with securities fraud have significantly larger ownership shares for institutional investors, as well as more highly geared stock options for managers, than other firms (Denis et al 2006).

${ }^{25}$ Flamholtz (1999).

${ }^{26}$ Chan et al (1990). In Britain, the market valuation of companies that do R\&D increases with spending on R\&D (Green et al 1996).
} 
top managers has been reined in following the scandals of the early 2000s. British companies are now encouraged to supplement financial reporting with narrative reporting, including information on changes in skills and training, so as to improve investors' information. ${ }^{27}$

Finally, there is evidence of earnings management even in unlisted US companies, associated with owners' wishes to assure their creditors of the company's health, and to facilitate any future flotation on the stock market. ${ }^{28}$ This complication spreads the scope of constraints on training across the corporate spectrum, weakening the distinction between listed companies and private companies, and making it more difficult to establish the effects of accounting conventions on training.

The question however is not whether the three constraints are present but whether they are strong enough to remove the postulated link between ownership and training. The enduring limits to the power of boards and activist investors to control managers are widely recognised. ${ }^{29}$ The reining in of stock options has not meant the end of highly geared performance-related pay for senior managers. ${ }^{30}$ Even though external investors see beyond reported earnings in valuing companies, their vision may still not be sharp enough to remove the benefit to managers of earnings management. ${ }^{31}$ Indeed, most chief financial officers in large US companies see the stock market as focused more on reported earnings than on cash flow, and as punishing severely any fall in, or any failure to meet analysts' consensus forecasts of, reported earnings. ${ }^{32}$

The incentive to the managers of companies with dispersed ownership to hold down spending on intangibles should be particularly marked for training, given its low measurability and external visibility, and particularly for apprentice training in occupations in which its cost to the employer is high and alternative sources of skill, notably recruitment and upgrade training, are also costly. ${ }^{33}$

Evidence on the association between ownership and training is however sparse. A study of the links between HRM practices and corporate ownership across British

\footnotetext{
${ }^{27}$ Monks and Minow (2008: chapter 2), Ferrarini and Moloney (2005), DTI (2003), ASB (2006).

${ }^{28}$ Graham et al (2005).

${ }^{29}$ Cheffins (2008), Cheffins and Bank (2009).

${ }^{30}$ Ferrarini and Moloney (2005).

${ }^{31}$ Narrative reporting has yet to realise in Britain the hopes attached to it, not least because of the limited informational content of the Key Performance Indicators that companies report annually (ASB 2009).

${ }^{32}$ Graham et al (2005).

${ }^{33}$ Ryan et al (2007), Bellmann and Janik (2007).
} 
workplaces found no significant relationship. ${ }^{34}$ Countries with larger equity markets have significantly smaller systems of initial vocational training. ${ }^{35}$ The paucity of prior evidence on the issue provides one motive for this study.

\section{Attributes of Ownership and Training in Three Countries}

This section outlines the similarities and differences between the three countries, in terms of, first, the three factors discussed in the previous section and, second, the relevant county-sector's initial training system. ${ }^{36}$

Table 1. Indicators of stock market size and activity, 2002

\begin{tabular}{cccc}
\hline & $\begin{array}{c}\text { Stock market } \\
\text { capitalisation as \% of } \\
\text { gross domestic } \\
\text { product }\end{array}$ & $\begin{array}{c}\text { New issues as \% of } \\
\text { gross fixed capital } \\
\text { formation }\end{array}$ & $\begin{array}{c}\text { Turnover velocity: } \\
\text { annual sales as \% of } \\
\text { market capitalisation }\end{array}$ \\
\hline GB & 111.0 & 12.6 & 97.3 \\
DE & 31.2 & 0.0 & 125.1 \\
CH & 183.1 & 0.0 & 138.6 \\
\hline
\end{tabular}

Source: http://www.world-exchanges.org/statistics/annual/2003

Notes:

a. Includes all shares in the domestically owned and some foreign owned (i.e., those not listed also in another country) companies that are listed in any of the country's stock markets

A leading contextual attribute is the importance of the stock market within the economy as a whole. Here the three countries differ sharply but unevenly. In terms of capitalisation, the stock market plays a small role in Germany, and a very large one in Switzerland, with Britain in between. It makes no ne t contribution to capital formation in Germany or Switzerland, and only a moderate one in Britain. Finally, although one

\footnotetext{
${ }^{34}$ Konzelmann et al (2006). The lack of association may reflect the limitations of the data used, notably the lack of differentiation of dispersed from blockholder ownership among listed companies, and the orientation of the training variables to adult training (incidence of and time spent in off-the-job training, and HR content of training).

${ }^{35}$ Black et al (2007). These results are hard to interpret because of the inclusion of full-time vocational schooling alongside apprenticeship in the dependent variable, and limited controls for other national attributes.

${ }^{36}$ Further evidence could be drawn from research on national institutions and economic performance. Thus 'coordinated' and 'liberal' market economies can be differentiated in terms of 'patient' and 'impatient' capital respectively, with associated differences in innovation, skills and training (De Jong 1997, Hall and Soskice 2001, Streeck and Yamamura 2001, Lazonick and O'Sullivan 2002). Differences in capital markets and corporate governance feature in such analyses (Vitols 2001, Höpner and Jackson 2006). The contribution of those studies to this paper's topic and methods is however limited by their emphasis on complementarities between capital markets, corporate governance and labour management (Höpner 2005) and on cross-national rather than intra-national variation in corporate finance and governance (Gospel and Pendleton, 2005, Cheffins and Bank 2009).
} 
might expect turnover velocity in share ownership - a potential indicator of shorttermism by investors - to be highest in Britain, it is markedly lower there than in the other two countries (Table 1). These data suggest an important role for listed companies with short-term oriented owners in both Britain and Switzerland, alongside a smaller-scale version of that in Germany.

\section{Corporate ownership, payment systems and accounting practice}

The previous section discussed the conditions under which companies with dispersed ownership can be expected to do less training than other companies. The evidence cited refers largely to the US. Even if those conditions apply there, they may not in Europe - as for example were the culture of American management radically different from its European counterparts. Moreover, even if they do apply to Europe, their importance may differ from country to country - as were management practice closer to its American counterpart in Britain than in Germany.

\section{Corporate ownership and finance}

Although the importance of dispersed ownership, and with it the 'managerial' firm, remains disputed, even for the $\mathrm{US},{ }^{37}$ it clearly features prominently there, and also in the three countries studied here. On a standard criterion (no single shareholder owns 20 per cent or more of the voting rights), among the largest 20 listed companies in the country in 1995, all the British ones had dispersed ownership, as did one half or more in Germany and Switzerland (50 and 60 per cent, respectively). Taking all listed (nonfinancial) companies, during 1996-99 the share of dispersed ownership, on the same criterion, was lower in all three countries, at 64 per cent in Britain, 26 per cent in Switzerland, and only 10 per cent in Germany, but the national differences remain marked. The difference between Britain and Germany in the prevalence of dispersed ownership was particularly large. In 1995, 83 per cent of listed British companies but only 17 per cent of German ones had no dominant owner. ${ }^{38}$

\footnotetext{
${ }^{37}$ Berle and Means (1932), Hannah (2007), Cheffins and Bank (2009). See also Morck et al (2005), Enriques and Volpin (2007).

${ }^{38}$ La Porta et al (1999: 492), Faccio and Lang (2002: 380), Barca and Becht (2001: Figures 1.9, 1.14). The difference between Germany and Britain is overstated by the latter data, as the German sample comprises only the 30 largest among the 436 firms listed on the Frankfurt Stock Exchange (DAX), whereas the British one comprises (a random sample of) all firms listed on the London Stock Exchange.
} 
The other side of the coin is that companies with a dominant owner also feature in all three countries, particularly in Germany. The leading variant within the category, family firms, accounted in 1996-99 for 25 per cent of listed firms in Britain, as compared to 56 per cent in Switzerland and 69 per cent in Germany. ${ }^{39}$ Painting the full picture would require the inclusion of unlisted firms, most of which are owned entirely by a single individual or family, and which are particularly prominent in Germany. ${ }^{40}$ The share of unlisted firms in headcounts of all businesses is high in all three countries (Appendix: Table A5). On an employment or turnover basis, however, the share of listed firms would be much higher in all countries, as such firms are mostly medium-sized or large. In Switzerland, for example, listed firms account for nearly one-fifth of corporate turnover (Table A6). ${ }^{41}$

The pressure that the stock market exerts on firms depends also on national business law and accounting practice. One potentially important factor is the degree to which incumbent management is protected in listed firms from hostile takeover bids. Differences between Britain and Germany were traditionally large here. The City Code of Practice governing takeover bids in Britain makes it difficult for managers to ward off a hostile bid, whereas until the last decade hostile takeovers were very rare in Germany, associated with the extensive roles played by bank finance, pyramid shareholdings, multiple control chains, cross-holdings, and non-voting shares. Such devices feature less commonly in Switzerland, despite considerable legal scope for their adoption. Moreover, Germany's two-tier board system and the presence of Works Councils in larger establishments impede further the acquisition of control over a target company. ${ }^{42}$

Differences between the three countries have declined in the past decade, with the expanded regulation of takeovers and the growth of merger activity in both Germany and Switzerland. ${ }^{43}$ At the same time, the managers of listed British firms, like their American counterparts, can be taken to be more exposed to a hostile

\footnotetext{
${ }^{39}$ Barca and Becht (2001).

${ }^{40}$ More than three-quarters of British unlisted companies were entirely owned by an individual in 1996; in the remainder, an individual owned at least one half (Goergen and Renneboog 2001: 275-6). See Noack and Zetzsche (2005) concerning Germany.

${ }_{41}$ Among listed Swiss firms, dispersed ownership, which applies to one half of the largest firms (above), accounts for only around one quarter of medium sized and small ones. Differences in the share of dispersed ownership by firm size are similarly large in Germany and in Britain (Faccio and Lang 2002: Table 5).

${ }^{42}$ Faccio and Lang (2002: Table 7), FBD (2006, 2009), Lambert et al (2010).

${ }^{43}$ Höpner (2003), Höpner and Jackson (2006). FBD (2009: Appendix 2) reports 33 takeover bids by large German firms during 2005-07 alone.
} 
takeover bid than are their (less numerous) counterparts in Germany and Switzerland. Their interest in keeping their company's share price high in order to discourage hostile bids should be correspondingly greater.

\section{Managerial remuneration}

The availability of cross-national evidence on payment systems for top managers is restricted by weaker disclosure requirements for listed companies in Germany than in Britain. One clear difference is a lesser use of stock options in Germany than in Britain. Among the large companies in the Eurotop 300 index in 2001, all of the British ones but only 57 per cent of the German ones give stock options to their top managers. More generally, differences in the importance of variable pay in listed companies appear to be closely associated with the importance among listed firms of dispersed ownership relative to block-holder ownership - though the data on which that conclusion is based appear scanty. ${ }^{44}$ Even less is known about the structure of management pay in unlisted firms in all countries.

Differences between Britain and Germany have declined in the past decade, with the growth of incentive pay in Germany, where the use of stock options was legally prohibited until 1998, and the move from stock options to long-term incentive bonuses in Britain, following the accounting scandals of the early 2000s. Little information is available on these attributes in Swiss companies.

\section{Accounting practice}

Finally, accounting practices have traditionally been similar in the UK and the US, while both have differed from continental European methods, in association with wider differences between common law and code law systems. 'Anglo-Saxon' accounting conventions serve primarily the needs of external, arms-length investors; continental ones, the needs of stakeholders, in particular large shareholders, banks, and employee representatives, whose 'insider' status reduces the importance of published accounts - in Germany relative in particular to the audit statement, which is circulated internally but not published.

Less stringent reporting requirements appear however to be associated in German and Swiss listed firms with more extensive earnings management than in

\footnotetext{
${ }^{44}$ Ferrarini et al (2003), Ferrarini and Moloney (2005). An anomalous finding in the former study is that variable pay (excluding stock options) amounted to 53 per cent of the total remuneration of Management Board members in Germany, but only 33 and 31 per cent of the pay of CEOs and other executives, respectively, in Britain.
} 
British and US ones, at least in terms of the handling of accruals to smooth income and avoid reporting a loss. ${ }^{45}$ It is not clear whether similar cross-national differences apply also to the manipulation of real activities, including training, or to unlisted firms. In any event, this evidence suggests that the analysis in the previous section is potentially relevant to listed firms in all three countries. ${ }^{46}$

Moreover, differences in national accounting systems have declined in recent years, with the dissemination of International Financial Reporting Standards, and German legislation that has installed many of the investor protection practices used in Britain and the US - though quarterly reporting has been avoided by some large German companies. $^{47}$

We therefore assume a broad similarity across the three countries in any pressure on companies with dispersed ownership, emanating from the stock market, to restrict spending on costly training programmes - and a contrasting lack of such pressure on other companies, particularly family-owned and unlisted ones. The difference may simply be that more companies are exposed to such pressures in Britain than in the other two countries. Moreover, during the past decade differences between Britain and Germany in terms of corporate governance and accounting practice have fallen markedly. ${ }^{48}$

\section{Initial training systems}

We take 'apprenticeship' to denote training programmes that combine vocational education with work-based learning, aimed at an intermediate occupational skill (i.e. more than routinised job training), and subject to externally imposed training standards, particularly for their workplace components. Evidence concerning apprenticeship has motivated the development of economic models of the supply and finance of training that focus on labour market factors. ${ }^{49}$

\footnotetext{
45 Grinyer et al (1998) find evidence of earnings management through R\&D spending in British companies. Similarly, whether a company operates an R\&D programme is sensitive to internal funding (cash flow) in Britain, but not in Germany, which suggests greater exposure to stock market pressures in Britain (Bond et al 1999).

${ }^{46}$ Leuz et al (2002), Leuz and Wüsterman (2004), Ben Otham and Zeghal (2006). Narrative reporting of non-financial indicators, including skills and training, is however more extensive in Germany than Britain, partly because of requirements for disclosure to Works Councils (PWC 2003).

${ }^{47}$ Nowak (2004), Noack and Zetzsche (2005), Baker and Barbu (2007), Volmer et al (2007).

${ }^{48}$ Höpner and Jackson (2006), Streeck (2009: chapter 6).

${ }^{49}$ Stevens (1994), Franz and Soskice (1995), Acemoglu and Pischke (1998).
} 
The three countries all possess a substantial amount of apprenticeship training. Germany and Switzerland occupy the top two places in international league tables of individual participation rates, with around two-thirds and three quarters of the youth population cohort respectively entering apprenticeship. ${ }^{50}$ By contrast, in England, the government hopes to raise the participation rate, based on a broad definition of apprenticeship, to one-fifth (DIUS 2008: 5).

Measuring the scale of apprenticeship is straightforward for Germany and Switzerland, where national legislation defines apprenticeship and provides for the setting of high training standards. A weak statutory framework means that in Britain apprentices cannot be clearly distinguished from other trainees and employees. ${ }^{51}$ By default, the standard criterion is participation in the Apprenticeships programme, through which the government funds most work-based learning for young people. As the content of employers' training programmes must conform to a 'framework' stipulated by a Sector Skills Council in order to receive public funding, the criterion is useful for counting 'apprentices' in Britain. ${ }^{52}$

Even so, as training standards vary greatly in Britain across frameworks, occupations and sectors, the question arises: how widely should the net be cast when counting Apprentices? The option chosen here is to include only Level 3 ('Advanced') Apprentices, for which - in industrial occupations at least - skill standards are comparable to those in German and Swiss apprenticeship. ${ }^{53}$

Table 2 shows the larger scale of operation of apprenticeship in Germany and Switzerland relative to Britain. ${ }^{54}$ Taking the economy as a whole, the number of apprentices amounts to 6.5 and 4.8 per cent of the number of employees in Germany and Switzerland respectively, but only 0.7 per cent in Britain.

\footnotetext{
${ }^{50}$ The participation rate in Germany averaged around 67 per cent during 1992-2009, falling below 60 per cent only in 2005 (BIBB 2010, Fig 2: 21); the Swiss rate averaged around 75 per cent during 19812007, never falling below 70 per cent (SKBF/CSRE 2010, Fig 93: 143).

${ }^{51}$ Ryan et al (2007). The 2009 Apprenticeship Act focuses on the Apprenticeships programme rather than generic apprenticeship (Parliament 2009).

${ }^{52}$ Ryan et al (2007).

53 Ryan and Unwin (2001), Steedman and Wagner (2003), Mason and Wagner (2005), Ryan et al (2007). The alternative is to include Level 2 Apprentices, but their training is typically aimed below intermediate (craft, technician) skill level, and most Apprentices, particularly at Level 2, receive little or no part-time vocational education in public colleges, a standard ingredient in the German and Swiss systems.

${ }^{54}$ Strictly speaking 'England', as the British establishments in our sample all operate primarily there (as in retailing) or entirely there (as in engineering). As Scotland and Northern Ireland operate their own public training programmes, our data for Britain refer mostly to England, either alone or in conjunction with Wales.
} 
Table 2. Apprenticeship activity by country and sector

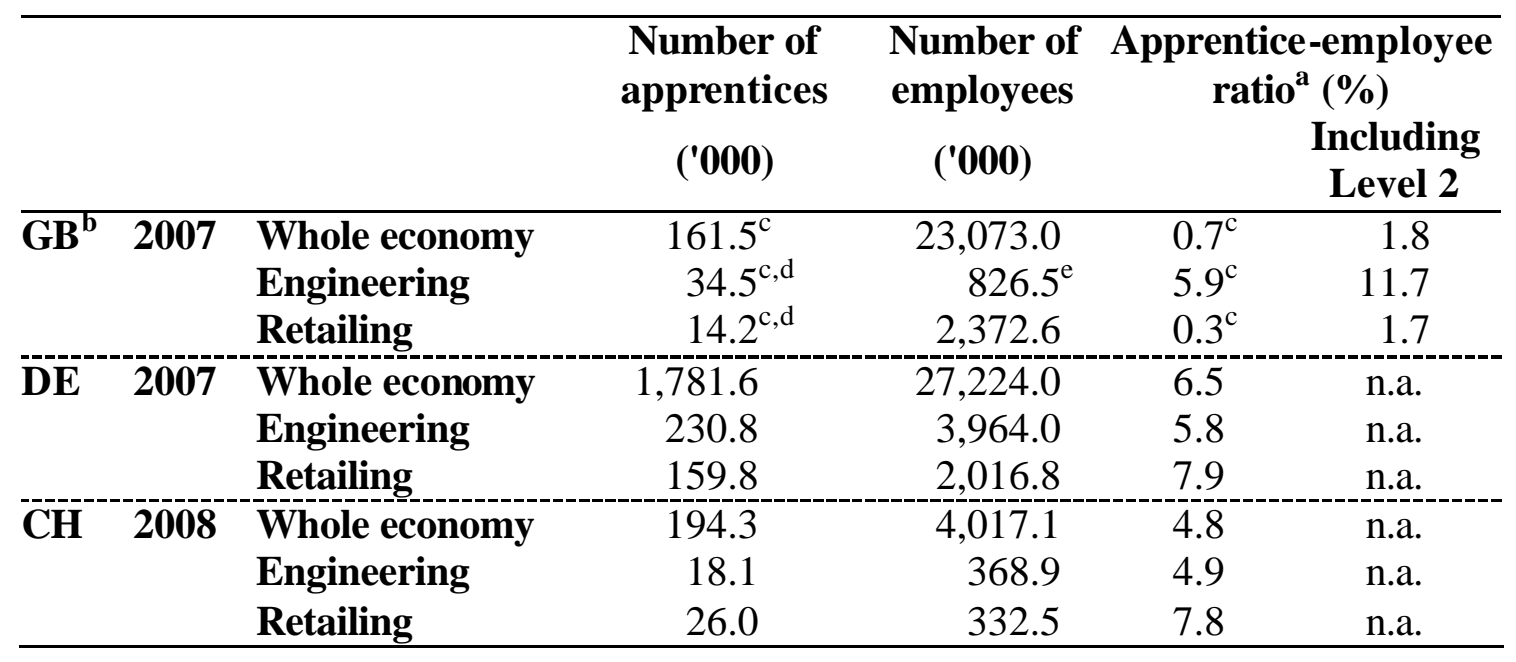

Sources: as in Ryan et al. (2010), Table 8.

Notes.

n.a.: not applicable.

a. Employment is defined as excluding apprentices in all countries;

b. England only;

c. Advanced Apprenticeship (i.e., Level 3 programmes) only;

d. Estimated on the assumptions that (i) the shares of different training frameworks in total participation are the same as in October 2004 and (ii) the breakdown between Level 2 and Level 3 Apprenticeship within frameworks is the same as that for programme leavers in 2004-05;

e. 'Employment jobs' in scope to SEMTA, 2007.

Does the same apply in engineering and retailing? International comparisons at sector level are complicated by mismatch between the occupation-based categorisation of training data and sector-based employment data, but that difficulty is not expected to differ greatly between the countries. In engineering, the apprentice ratio in Britain (5.9 per cent) is comparable to that in both Germany and Switzerland (5.8 and 4.9 per cent, respectively). ${ }^{55}$ The gap between training rates in Britain and the other two countries is however large in retailing: an apprentice ratio of nearly eight per cent in both Germany and Switzerland, as against only 0.3 per cent in Britain. The difference between England and the other countries reflects the widespread preference of English retailers for informal on-the-job training rather than apprenticeship.

The national apprenticeship systems differ also in content. In both Germany and Switzerland, apprentices spend one to two days a week in formal education at a

\footnotetext{
55 The British ratio rises to 11.7 per cent if Level 2 Apprentices are included, but that figure is misleading, given the limited content of Level 2 programmes compared to apprenticeship in the other countries. Level 2 Apprenticeships resemble Anlehre and Attestausbildung ('elementary apprenticeship') programmes for low achievers in Switzerland, taken by around 3 to 4 per cent of secondary-level graduates.
} 
vocational college. In Britain, the same applies to engineering Apprentices, most of whom spend their first nine months entirely off the job, in colleges and training workshops, and subsequently attend a further education college on a part-time basis. But it does ot apply to Apprentices in retailing. They inhabit one of the recently created training occupations in the service sector; they spend little time away from the immediate job; and they rarely receive any continuing education, vocational or general. ${ }^{56}$ Their training actually resembles more the informal, staged training offered by larger retailers to recent recruits, which remains the predominant form of initial training in the sector (Lewis et al 2008). ${ }^{57}$

Table 3. Cost of an apprenticeship to the employer (£K, 2000)

\begin{tabular}{|c|c|c|c|c|c|c|}
\hline & & Occupation & $\begin{array}{c}\text { Duration } \\
\text { (years) }\end{array}$ & $\begin{array}{c}\text { Gross } \\
\text { cost }\end{array}$ & $\begin{array}{c}\text { Output } \\
\text { during } \\
\text { training }\end{array}$ & $\begin{array}{l}\text { Net } \\
\text { cost }\end{array}$ \\
\hline \multirow[t]{3}{*}{ Engineering } & GB & Level 3 Apprenticeship ${ }^{\text {a }}$ & 3.5 & 43.8 & 28.4 & 15.4 \\
\hline & DE & Mechatroniker & 3.5 & 64.8 & 10.8 & 54.0 \\
\hline & $\mathbf{C H}$ & Polymechaniker & 4 & 55.5 & 45.3 & 10.2 \\
\hline \multirow[t]{3}{*}{ Retailing } & $\mathbf{G B}$ & Level 3 Apprenticeship ${ }^{\mathrm{a}}$ & 2 & 23.0 & 22.9 & 0.1 \\
\hline & $\mathbf{D E}$ & Kaufmann/frau & 3 & 30.4 & 16.0 & 14.4 \\
\hline & $\mathbf{C H}$ & Detailhandelsangesellter & 3 & 27.7 & 30.2 & -2.5 \\
\hline
\end{tabular}

Sources: Hogarth and Hasluck (2003: Tables 3.1, 5.2), Beicht et al (2004: 156-7), Mühlemann et al (2007: 55-60).

Notes:

Average across samples of employers; costs estimated on an average accounting cost (Vollkosten) basis; net cost is gross cost minus the estimated value of output during training. Converted to $£ \mathrm{~K}$ (2000) using the GDP price deflator (GB) and the mid-year sterling exchange rate.

Years: GB, 2002; DE, 2000; CH, 2004.

a . Excludes public training grants received by the employer

b. Kaufmann/frau im Einzelhandel

Finally, in engineering, apprenticeship training involves in all three countries substantial costs for the employer, as training regulations require apprentices to spend a substantial amount of time in part-time vocational education and learn a wide range of skills on the job. In retailing by contrast, a higher ratio of apprentice output during

\footnotetext{
${ }^{56}$ One-third of all Apprentices (Levels 2 and 3 combined) claim to receive no off-the-job training. Time spent in off-the-job training averages between one and four hours per week in most service sector Apprenticeships, with Retailing and Customer Service at the one hour end of the spectrum (Ullman and Deakin 2005: 3, 15).

${ }^{57}$ The Apprenticeship programme differs from its Germanic counterparts also in centring on: (i) public subsidies to a range of training providers, many of them for-profit organisations; and (ii) contractual relationships and external inspection, rather than administrative hierarchy, social partnership and peer monitoring (Lewis and Ryan 2009, Ryan 2010).
} 
training to pay means much lower costs to the employer on average in Germany, in Britain almost no net cost, and in Switzerland a modest surplus (Table 3). ${ }^{58} \mathrm{We}$ therefore expect any effects of ownership on the supply of training to be stronger in engineering than in retailing.

\section{Sources of Evidence}

Our evidence concerns 56 establishments in engineering (i.e. metalworking) and retailing, in Britain, Germany, and Switzerland. We targeted establishments and companies for inclusion with a view to matching them across the three countries by their products or services, as indicated by four-digit SIC codes, in order to hold broadly constant the influence of products and technologies on skills and training. We differentiated potential targets in terms of bargaining coverage and corporate ownership, the variables whose associations with skills and training are of specific interest.

In engineering, the sample is dominated by producers of pumps, turbines, and compressors - sub-sectors for which comparable establishments could be identified in all three countries. In retailing, most companies are department stores or multiple outlet chains (in food, shoes, electronic products, and furniture). Most of the businesses are single establishments or groups of establishments (e.g. a regional division) within a large company. Several are owned by a foreign company, and some have the same multinational parent. ${ }^{59}$

The distribution of initial training practice across cases is skewed. In Germany and Switzerland, all but one of the establishments operates an apprenticeship programme; in Britain, all of the engineering establishments, but none of the retailing establishments, do so. ${ }^{60}$ The British establishments all use in-house bespoke training programmes for newly hired sales staff.

We sought to include a variety of types of corporate ownership, ranging from cooperatives through unlisted private companies, to listed companies with and without dispersed ownership - and in particular to include dispersed ownership companies in each sector-country category. That goal was attained only in part (Table 4). Less than

\footnotetext{
${ }^{58}$ Table 3 excludes the two year (Verkäufer) programmes that operate in German and Swiss retailing.

59 All of the engineering cases, but in retailing only the department stores, are single establishments. Statistical details are provided in Appendix A.

${ }^{60}$ Two of the British retailers actually offer Apprenticeships but only outside the establishment or region studied.
} 
one quarter (12 out of 56) of our cases are listed companies with dispersed ownership. In the UK, the share is nearer to one half (eight out of 19), and in engineering slightly more than one half (five out of nine). But in the German and the Swiss samples only four companies have dispersed ownership, none of them in retailing.

A breakdown of the 'other' category shows considerable heterogeneity: a predominance in all three countries of unlisted firms owned by a family, foundation or cooperative (26 cases), followed by listed firms with one or more large blockholders (13), along with a handful of unlisted firms owned by a small number of investors, including one British retailer financed partly by a private equity fund (Appendix Table A4).

Table 4. Ownership of participating employers

\begin{tabular}{llcccc}
\hline & & GB & DE & CH & All \\
\hline Engineering & Listed, dispersed & 5 & 1 & 3 & 9 \\
& Other & 4 & 7 & 6 & 17 \\
& All & 9 & 8 & 9 & 26 \\
\hline Retailing & Listed, dispersed & 3 & 0 & 0 & 3 \\
& Other & 7 & 10 & 10 & 27 \\
\hline Both & All & 10 & 10 & 10 & 30 \\
& Listed, dispersed & 8 & 1 & 3 & 12 \\
& Other & 11 & 17 & 16 & 44 \\
& All & 19 & 18 & 19 & 56 \\
\hline
\end{tabular}

Notes.

'Listed, dispersed': the company (or its ultimate parent) company is listed on any stock market and no shareholder owns 20 per cent or more of its shares (with voting rights).

The uneven distribution of the sample by ownership clearly reflects national attributes, and probably selection effects too. Dispersed ownership companies play a smaller role in Germany and Switzerland than in Britain (section three above). This appears to be particularly marked in retailing, where unlisted firms and family ownership dominate. But selection effects appear influential too. The refusal rate among target companies was highest in Britain, particularly among listed retailing companies with a recent history of financial upheaval, including leveraged buy-outs. ${ }^{61}$

\footnotetext{
${ }^{61}$ Such companies proved particularly effective at frustrating our attempts to identify managers and contact them by phone, at both central and store levels. However, four listed British retailers agreed eventually to participate, two after we moved our request from head office to particular stores, and one through personal contacts.
} 
Our information comes primarily from face-to-face semi-structured interviews with senior managers. As the wider project focuses primarily on pay structure and training, our interviewees were typically managers of HR/personnel or training departments. We did not request interviews with a senior financial manager as well, as we expected that to jeopardise our targets' willingness to participate. Our internallyacquired information on financial factors comes therefore from the perceptions of HR managers, concerning the effects of financial shocks, actual or hypothetical, on training decisions. We also met officials of employers' associations and trade unions with interests in the relevant sector.

The interviews were conducted between April 2008 and May 2009, during the recession that followed the international financial crisis. Information on ownership and financial upheavals was compiled primarily from public sources, including the company's website and annual reports, and filings with regulatory authorities (notably Schedule $13 \mathrm{G}$ Filings for US-based companies). ${ }^{62}$ Further details are provided in the Appendix.

\section{Findings}

We use two types of evidence on the effects of finance and ownership on training. The first is association between ownership attributes and training - which, given that almost all employers except British retailers offer apprenticeship, concerns primarily the number of apprentices trained. The second source is the association that interviewees perceive between financial shocks and changes in training.

We do not investigate separately the three factors discussed in section two, apart from documenting the incidence of dispersed ownership in our sample. Companies are not expected willingly to disclose details of their managerial payment systems and accounting practices.

Interest focuses primarily on engineering, a sector in which an apprenticeship imposes substantial costs on the employer, and only secondarily on retailing, in which costs are at small, even negative (Table 3, above).

\footnotetext{
${ }^{62}$ In all three countries, listed companies are required to publish the presence and identity of owners of stakes that exceed stipulated thresholds, starting at five per cent of total equity.
} 


\section{Ownership type and training intensity}

Do listed companies with dispersed ownership do more initial training than otherwise comparable companies? We compare companies' current apprentice ratios (i.e. the ratio of apprentices to employees in the largest training occupations) across the two ownership categories. As the intensity of training is expected to vary by technology (as a determinant of skill requirements), we focus on differences within two four-digit engineering categories: pumps, and turbines and compressors. We define dispersion of ownership as the absence of any shareholder with at least 20 per cent of voting rights. $^{63}$

Table 5. Apprentice ratios in engineering subsectors by ownership and country $(\%)$
All
GB
DE
CH

\begin{tabular}{lcccccccc} 
& $\begin{array}{c}\text { Listed, } \\
\text { dispersed }\end{array}$ & Other & $\begin{array}{c}\text { Listed, } \\
\text { dispersed }\end{array}$ & Other & $\begin{array}{c}\text { Listed, } \\
\text { dispersed }\end{array}$ & Other & $\begin{array}{c}\text { Listed, } \\
\text { dispersed }\end{array}$ & Other \\
\hline (1) Pumps & 2.1 & 8.8 & 2.1 & 9.0 & - & 6.9 & - & 11.1 \\
$\begin{array}{l}\text { (2) Turbines, } \\
\text { compressors }\end{array}$ & 9.7 & 11.9 & 9.7 & - & 11.4 & 7.4 & 8.2 & 14.1 \\
$(\mathbf{1})+(\mathbf{2})$ Both & 7.2 & 9.6 & 5.9 & 9.0 & 11.4 & 7.0 & 8.2 & 12.3 \\
\hline \# firms (1) & 2 & 9 & 2 & 2 & 0 & 4 & 0 & 3 \\
$\#$ firms (2) & 4 & 2 & 2 & 0 & 1 & 1 & 1 & 2 \\
$\#(\mathbf{1})+\#(2)$ & 6 & 11 & 2 & 2 & 1 & 5 & 1 & 5 \\
\hline
\end{tabular}

Notes:

Unweighted averages of companies' ratio of stock of apprentices to employment (excluding apprentices) in production and maintenance departments, excluding the one (Swiss) company with no apprenticeships.

Dash: not applicable (no case in category).

Table 5 shows that the six listed engineering companies with dispersed ownership have lower training intensities than do the 11 'other' ones: 2.1 per cent compared to 8.8 per cent in pumps, 9.7 per cent compared to 11.9 per cent in turbines and compressors. ${ }^{64}$ To that extent, the evidence is consistent with the hypothesis. It is

\footnotetext{
${ }^{63}$ If the threshold stake is reduced to 10 per cent, only one firm (a large British electrical retailer) moves from 'dispersed' to 'other', indicating that the classification is not sensitive to choice of threshold.

${ }^{64}$ The single (Swiss) engineering firm that does not train apprentices is excluded.
} 
however complicated by the skewed distribution of ownership types across countries: our Swiss and German samples have only no 'listed, dispersed' cases in pumps and only one each in turbines; the British sample, no 'listed dispersed' case in turbines. Any ownership effects on training may therefore be proxies for national effects.

The most informative evidence is that for the British pump companies, with two cases in each ownership category, and each pair comprising one producer of smaller pumps in larger batches and one producer of larger pumps in smaller batches. The considerable difference in training intensity by ownership (2.1 compared to 9.0 per cent) is again consistent with the hypothesis of ownership effects on training, and it is not polluted by any country-specific effects.

A further comparison becomes viable using the data in Table 5 if differences between Germany and Switzerland in national training-related factors are taken to be small - as might be expected from a 'varieties of capitalism' standpoint. The five German and Swiss turbine firms comprise three with dispersed ownership and two 'others'. Training intensity averages 9.8 per cent for the two dispersed ownership cases, as compared to 11.9 for the three 'others'. The difference, albeit modest, is also consistent with the hypothesised ownership effects.

Differences across companies are substantial, and even suggest that 'company' effects may dominate ownership effects. The two establishments in each of the British and German samples that have the highest apprentice ratios, taking pumps, turbines and compressors as a whole, are owned by the same two multinationals. The similarity of these plants' training efforts is not however mirrored in their parents' ownership structures: both are listed companies, but one has dispersed ownership (largest stake well below 10 per cent), while the other has a dominant block-holder (more than 25 per cent).

This analysis cannot be extended to retailing, given the absence of apprenticeship in the British sample and of dispersed ownership in the German and Swiss ones. What can be said is that the evidence suggests no ownership effect in British retailing: despite low training costs, none of the British retailers, not even a cooperative department store chain with a strong reputation for training, provides Apprenticeships. This aspect of British training practice appears to be independent of corporate ownership. 


\section{Financial shocks and training}

The second source of evidence on ownership effects is the link between financial upheaval and training. Section two discussed evidence that earnings management is encountered frequently in listed companies that in its absence would miss earnings targets, including breaking even and meeting analysts' consensus forecasts. Financial shocks tend to generate such situations. We therefore asked interviewees about any substantial recent financial upheavals in their companies, including those that we had already identified from public sources. When none had occurred we asked about a hypothetical takeover by a private equity fund.

Taking actual upheavals first, two issues arise. First, have listed companies with dispersed ownership experienced more financial upheavals than have other companies? Second, to what extent have those upheavals affected training decisions? We distinguish two broad categories of financial upheaval: a major fall in the company's stock price, and any substantial change in ownership the establishment had experienced in recent years, including a change of dominant owner or a large external investment. ${ }^{65}$ Such events feature moderately frequently (Table 6). Almost one half of participating companies (27 out of 56) have experienced at least one financial upheaval. The incidence is particularly high in Britain, at around two-thirds (13 out of 19), as compared to less than one-third (five out of 18) in Germany and around one half in Switzerland (nine out of 19). Ownership change features more often than a fall in share price.

Differences between countries result at least partly from ownership attributes (Table 7). Financial upheaval is the norm among participating companies with dispersed ownership: only one has not recently had such an experience. By contrast, only one-third (14 out of 42) in the 'other' category report a financial upheaval. ${ }^{66}$ Dispersed ownership companies report a share price fall more often than do 'others' which is hardly surprising, given that only a minority of the latter have a share price (i.e. are listed). Less obvious ex ante is the substantial incidence of changes in ownership among 'other' companies, with one half (six out of 10) 'other' companies in Britain experiencing such an event (Table 8). The substantial incidence of financial

\footnotetext{
${ }^{65}$ The distinction between financial and other upheavals in our evidence is not sharp. In several cases, weak performance in product markets preceded financial upheaval.

${ }^{66}$ Reporting bias may be present here, insofar as the dominant source of our information for unlisted companies are interviewees themselves, whereas more published information is available for listed companies.
} 
upheaval in Switzerland applies primarily to engineering, reflecting the past decade's extensive restructuring. ${ }^{67}$

Table 6. Incidence of financial upheaval in engineering and retailing companies

\begin{tabular}{lcccc}
\hline & UK & DE & CH & All \\
\hline (1) Fall in share price & 7 & 2 & 4 & 13 \\
(2) Ownership: takeover, merger/demerger, etc. & 10 & 4 & 7 & 21 \\
Either (1) or (2) & 13 & 5 & 9 & 27 \\
Both (1) and (2) & 5 & 1 & 2 & 8 \\
\hline Number of companies & 19 & 18 & 19 & 56 \\
\hline
\end{tabular}

Note.

Occurrence during the past decade (in some cases, two decades) for the company of (i) a substantial (as judged by the interviewer or the interviewee) fall in the (parent) company's share price, or (ii) a change of owner, through takeover, merger (or demerger), change of large owner, or large external investment (excluding acquisitions of other companies).

Table 7. Incidence of financial upheaval by ownership and country

\begin{tabular}{lcccccccc}
\hline & \multicolumn{2}{c}{ GB } & \multicolumn{2}{c}{ DE } & \multicolumn{2}{c}{ CH } & \multicolumn{2}{c}{ All countries } \\
& Yes & No & Yes & No & Yes & No & Yes & No \\
\hline Listed, dispersed & 8 & 1 & 2 & 0 & 3 & 0 & 13 & 1 \\
Other & 5 & 5 & 3 & 13 & 6 & 10 & 14 & 28 \\
All companies & 13 & 6 & 5 & 13 & 9 & 10 & 27 & 28 \\
\hline
\end{tabular}

Note:

Yes (no): occurrence of at least one (no) financial shock in company

55 companies for which information was available

Table 8. Incidents of financial upheaval by ownership category and country

\begin{tabular}{lcccccccc}
\hline & \multicolumn{2}{c}{ GB } & \multicolumn{2}{c}{ DE } & \multicolumn{2}{c}{ CH } & \multicolumn{2}{c}{ All countries } \\
& Merger & $\begin{array}{l}\text { Share } \\
\text { price }\end{array}$ & Merger & $\begin{array}{c}\text { Share } \\
\text { price }\end{array}$ & Merger & $\begin{array}{l}\text { Share } \\
\text { price }\end{array}$ & Merger & $\begin{array}{l}\text { Share } \\
\text { price }\end{array}$ \\
\hline $\begin{array}{l}\text { Listed, } \\
\text { dispersed }\end{array}$ & 4 & 6 & 1 & 1 & 2 & 2 & 7 & 9 \\
Other & 6 & 1 & 3 & 1 & 6 & 3 & 15 & 5 \\
All companies & 10 & 7 & 4 & 2 & 8 & 5 & 22 & 14 \\
\hline
\end{tabular}

Notes:

Only companies with (one or more) financial shocks; some companies appear in both categories of shock.

'Merger': the company was merged into or taken over by another company or had a change of majority ownership; its own acquisitions are not included

\footnotetext{
${ }^{67}$ Engineering accounts for seven out of the nine Swiss companies with financial upheaval.
} 
What effect do these financial changes have on training? We consider the issue first for all financial upheavals and second for the subset of shocks that involve a move between the 'listed, dispersed' and 'other' categories.

Table 9 shows that financially-induced retrenchment of training is not widespread in our sample. It has occurred in only seven companies, in five of which the cuts involved initial training, and in the other two, continuing training. Financial upheavals affect training, for better or worse, somewhat more often in Britain (eight out of 13 cases) than in the other countries (six out of 14 cases). The extreme case is a small Swiss engineering company, which abandoned its apprenticeship programme in the aftermath of its takeover by a multinational. Type of ownership does not however appear to be involved, as the change was one closely held firm (family-based foundation) to another (foreign family), which is also based in a country with an extensive apprenticeship system.

Table 9. Effects of financial upheaval on training in participating companies

\begin{tabular}{llcccc}
\hline Effect & & UK & DE & CH & All \\
\hline Initial training & Less & 4 & 0 & 1 & 5 \\
& More & 5 & 0 & 0 & 5 \\
Other training & Less & 1 & 0 & 1 & 2 \\
& More & 1 & 1 & 1 & 3 \\
HR centralisation & & 2 & 0 & 0 & 2 \\
Other & 1 & 0 & 0 & 1 \\
None & 5 & 1 & 6 & 12 \\
No information & 0 & 3 & 0 & 3 \\
All & & 5 & 5 & 9 & 27 \\
\hline
\end{tabular}

Note:

Effect on training: judgement by interviewee(s). Initial training: apprenticeship or other initial training. Data are confined to cases for which information was obtained. Cases in which training was cut as a result of a fall in expected future requirements for skilled labour are not included.

Cutbacks in training, whether in initial or continuing training, in quantity or content, that are linked to a financial upheaval are present mostly among the British companies - and, paradoxically, more in retailing than in engineering. Again, interest focuses primarily on apprenticeship training in engineering companies with dispersed ownership. Given the external regulation of training standards in all three countries, employers' choices concern the volume more than the content of training. Of the ten establishments (in six companies) in this category, nine report having had one or more financial upheavals. However, in only one did a financial shock affect apprentice 
training significantly: a profitability crisis 15 years ago that caused the intake of apprentices to be suspended. ${ }^{68}$ Even that instance has limited weight, as the resulting imbalance in the age and skill structure of the company's workforce meant that in the two subsequent shocks the apprenticeship programme remained unaffected. ${ }^{69}$ Otherwise any effects reported are secondary - such as the recent postponement by a German pumps company of a planned refurbishment of its training centre, and the bringing in-house by a British engineering company of the Key Skills component of its Apprenticeship programme.

By contrast, the three British retailers that are listed companies with dispersed ownership have all experienced one or more sharp falls in their stock price, to which all responded with cutbacks. Those cuts involve the content of (non-Apprenticeship) training: the amount of that type of training that retailers undertake depends directly on the labour turnover rate that they experience in sales occupations. The strongest response came from a retailer of electrical and electronic goods, which, in response to a recent drastic fall in profits and share price, reduced the content of training for store managers and sales staff, and converted training for sales staff from personal instruction by the store manager to self-instruction using in-store IT equipment. The HR manager anticipated adverse effects on training quality from both changes.

In response to similar difficulties, a second company reduced the duration of initial training for sales staff from three days to two, while trying to strengthen the link between training and customer service, to give staff the skills and motivation to sell more. The third company cut off-the-job training for managers, which was seen as relatively expensive and of questionable efficacy. In all three cases, interviewees saw a conflict between financial pressures for cost reduction and a competitive need to maintain customer service through staff training. These cases suggest that in dispersed ownership companies even short, low cost training programmes can be prone to cuts as a result of cost pressure in a crisis.

Broader repercussions were reported in two other cases, both in Britain, in which the HR/personnel function was restructured. An engineering company not only centralised HR management from plant to company level, but also made the plant's

\footnotetext{
${ }^{68}$ The pattern would change were training cuts associated with employment reduction included. The three engineering companies that reported such episodes were all dispersed ownership companies at the time of the cuts.

${ }^{69}$ A similar experience and response was reported by a large Swiss engineering plant with a dominant blockholder (its CEO).
} 
apprenticeship manager compulsorily redundant, a move that was seen as endangering training quality.

Not only are changes in training in response to financial shock a minority experience in our sample, in eight cases the perceived effect on training is expansion, not contraction. The scenario typically involves a crisis-induced review of the company's activities, leading to the reformulation of corporate strategy based around the quality of products or services, and with more training and skills viewed as necessary for success.

Finally, changes in ownership may have effects on training. Five companies changed (in either direction) between 'listed, dispersed ownership' and 'other' status. Three moved from listed, dispersed status: one engineering plant and two department stores, all in Britain. The engineering company reported that its new, foreign owner had not - at least not yet - attempted to influence its training decisions. The two retailers saw the change to private ownership by a hands-on individual as making possible their recent increases in spending on training - consistent with the hypothesised ownership effect.

The two companies that moved to dispersed ownership were engineering companies, one British, the other Swiss. No adverse effect on the apprenticeship programme was perceived in either case. Managers attribute that in both cases to a high priority to skills and training on the part of the new owners, both of them multinationals - dispersed ownership notwithstanding. These cases do not support the hypothesised ownership effect. Nevertheless, in the Swiss case, the HR manager would have expected adverse effects had the share offering been taken up by an organisation intent on short-term financial gain, notably a private equity fund. A similar concern is stated in two further Swiss engineering companies whose ownership has been in flux. Their concerns may reflect the potential threat to the interviewees' own jobs, but training and skills could well have been jeopardised by a move to that particular type of dispersed ownership.

\section{Hypothetical sale to private equity}

Managers' views on the effects of a hypothetical sale to private equity were mixed. ${ }^{70}$ Some managers of British companies had personal knowledge of such events in

\footnotetext{
${ }^{70}$ The threat posed by external takeover was formulated in terms of private equity for its dramatic potential, despite the marginal status of the threat in Germany and Switzerland, and the possibility that private equity funds have less short-term horizons than does mainstream dispersed ownership.
} 
competitor firms. A manager in a department store owned by an employee trust remarked that 'if we had to react in the way that some other retailers do to shareholder pressure, we would not be in the long term business that we are ... we're not subject to the same pressures'. Her counterpart in another privately owned company said however, 'it's hard to say .... some private equity funds have a long-term view.' Also valuable are the statements of a food retailer and a shoe retailer, both of whom had experience of private equity funding, the first by acquiring a company from such a fund, the second by having a fund invest in it. Neither change was seen as having any visible effect on training.

In Germany, two companies - an engineering one owned by a foundation and an electronics retailer owned by a family - stated that their low debt burden and high rate of re-investment of profits are both made possible by their ownership structure, and could not be expected to continue were private equity in charge, with potentially adverse implications for training. On the other hand, two Swiss retailing companies thought that an increase in apprenticeship training would be on the cards, as in their sector apprentices earn money for their employers, and a private equity concern could be expected to exploit that advantage more extensively.

Overall, of the 32 firms that gave a view on the issue, 14 would expect no effect, 15 would expect cuts in training, and the two Swiss retailers would expect an increase.

\section{Product market competition}

Product markets may be more important influences on skills and training than are financial markets. Although some theories predict that greater competition between companies in product markets leads under particular conditions to less training, statistical evidence does not support that proposition. ${ }^{71}$ Moreover, companies' training efforts have been found to depend positively on product competition (importance of quality) and inversely on product diversity and batch size, while financial factors influence primarily the type of training used (apprenticeship as opposed to upgrade). ${ }^{72}$

Our evidence also goes against any expectation that competition reduces training. Most interviewees describe competition in the company's product market(s) as strong; almost all of those who responded to the question also see product market

\footnotetext{
${ }^{71}$ Miller (1997), Görlitz and Stiebale (2008). Adverse effects on training are predicted when any firms that provide general training are required by exo genous pay structure to invest in trainees.

${ }^{72}$ Backes-Gellner (1996).
} 
competition as supporting spending on training. That view is particularly marked in retailing (Table 10), where most companies see a high standard of customer service as essential for competitive advantage, and training in sales skills and product knowledge as essential for good customer service. Particularly striking is a privately owned German discount food retailer, whose initial business model had involved low service and low prices. It now gives priority to broadening its range of products and improving customer service, and it has raised pay for apprentices in order to attract better applicants.

Table 10. Product market competition and training

Number of companies answering 'yes'/number of companies for which information was obtained

\begin{tabular}{llcc}
\hline Engineering & UK & $\begin{array}{c}\text { Company faces strong } \\
\text { competition in product } \\
\text { market }\end{array}$ & $\begin{array}{c}\text { Product market } \\
\text { competition has a strongly } \\
\text { positive effect on training }\end{array}$ \\
& Germany & $4 / 8$ & $6 / 7$ \\
Retailing & Switzerland & $3 / 8$ & $2 / 5$ \\
& UK & $4 / 9$ & $7 / 8$ \\
& Germany & $8 / 10$ & $9 / 10$ \\
Both & Switzerland & $9 / 10$ & $5 / 5$ \\
\hline
\end{tabular}

The situation in engineering is broadly similar, insofar as all of the companies produce at least some bespoke products, as one-offs or small batches, and design, sales, and after-sales service, which account typically for an increasing share of revenues, involve high levels of customer contact, for which both technical and social skills are important. At the same time, as these engineering companies specialise more by detailed product and face less intensive price competition than do retailers, it is perhaps not surprising that, in Germany at least, they less often rate product market competition and its effects on training as strong.

The difference between the two sectors is however less marked in British and Swiss than in German engineering, suggesting a more precarious situation among British and Swiss than among German engineering firms. 


\section{Conclusions}

This paper has outlined the conditions under which corporate ownership and finance may be expected to influence a firm's supply of training. Our analysis is formulated in terms of three interdependent factors: listed status with dispersed ownership, highly geared incentive pay for managers, and accounting conventions and stock market myopia. The managers of 'stock market firms' whose pay depends strongly on reported earnings or the company's share price have incentives to hold down spending on intangible assets in order to increase their own remuneration. In closely held firms, by contrast, managers' decisions are subject to direct monitoring by owners, who have less interest in offering their managers highly geared bonus pay, and are better placed to perceive the long-term interest of the firm and give it priority over short-term benefits.

The effects of corporate ownership are expected to be particularly strong for training programmes that impose on the employer a high cost per trainee - as for apprenticeship training in engineering skills. Even in such a context, however, the difference between the two types of firm may be weak or absent. Managerial 'selfdealing' may be curbed by effective corporate governance, by investor cooperation and activism, by a limited use of performance-related payment for managers, and by an ability among even arms- length investors to see behind current reported earnings in valuing the business. Moreover, earnings management may focus more on smoothing reported profits over time than on maximising their current magnitude - in which case its implications for training become more a matter of durable restriction rather than short-termist manipulation.

Our evidence, taken from a project focused principally on the labour market aspects of initial training, is consistent with the proposition that, in engineering at least, listed companies with dispersed ownership do less training in normal times than do matched plants with other kinds of ownership, including listed firms with blockholder ownership and privately owned firms. Second, dispersed ownership companies are more prone to financial upheaval, defined in terms of ownership changes and falls in share prices, than are other types of company. We encountered some firms in which such financial changes had led to cutbacks in training - primarily in Britain, and, surprisingly, more often in retailing than in engineering. 
We do not find, however, that financial upheaval has generally adverse effects on initial training. Indeed, when associated with a new start for an ailing business, it can mean the expansion of or improvement in training, not budget cuts and retrenchment. In this respect, the requirements of product markets provide some buoyancy to corporate training efforts, even in listed companies with dispersed ownership in British engineering, in which apprenticeship training is particularly costly for the employer.

Our evidence comes from only a limited number of companies, whose representativeness is uncertain. It lacks controls for such potential influences on training as future requirements for skilled labour and the cost of potential substitutes for initial training, notably recruitment and upgrade training. As the strength of ownership effects appears to be limited, larger and more representative datasets are needed if more definitive evidence is to be found.

\section{Acknowledgements}

We would like to thank: the Anglo-German Foundation, the Hans-Böckler Stiftung, the ESRC research centre on Skills, Knowledge and Organisational Performance (SKOPE), the Federal Office for Professional Education and Technology (OPET), Berne, and Wissenschaftszentrum Berlin for financial and other support; managers and officials in the participating employers, employers' associations and trade unions, for participation in the project; participants at colloquia held by Hans-Böckler Stiftung for suggestions and comments; Michaele Kuhnhenne and Christian Dustmann for support and guidance; Jim Foreman, Christian Busin, Jerome Lutz, Katherine Meyer and Andrea Willi for research assistance; Barbara Müller, Statistisches Bundesamt, Bundesamt für Statistik, the Learning and Skills Council, and Bureau van Dijk Electronic Publishing (BvDEP), for providing data; and Howard Gospel, Alan Hughes, and Barbara Müller for helpful suggestions.

\section{References}

Acemoglu, D. and J.-S. Pischke (1998), 'Why do firms train? Theory and evidence', Quarterly Journal of Economics, February, 79-119.

Anderson, R.C. and D.M. Reeb (2003), 'Founding family ownership and firm performance', Journal of Finance, 58(3), 1301-28.

Armour, J., S. Deakin and S.J. Konzelmann (2003), 'Shareholder primacy and the trajectory of UK corporate governance', British Journal of Industrial Relations, 41(3), 531-55.

ASB (2006), Reporting Statement: Operating and Financial Review. London: Accounting Standards Board. 
ASB (2009), A Review of Narrative Reporting by UK Listed Companies in 2008/2009. London: Accounting Standards Board.

Atrill, P. and E. McLancy (2008), Financial Accounting for Decision Makers, $5^{\text {th }}$ ed.. Harlow: Pearson Education.

Backes-Gellner, U. (1996), Betriebliche Bildungs- und Wettbewerbsstrategien im deutsch-britischen Vergleich. Munich: Hampp.

Baker, C.R. and E.M. Barbu (2007), 'Evolution of research on international accounting harmonisation: a historical and institutional perspective', SocioEconomic Review, 5(4), 603-32.

Barca, F. and M. Becht (2001), The Control of Corporate Europe. Oxford: OUP.

BBT (2010), Berufsbildung in der Schweiz: Fakten und Zahlen. Bern: Bundesamt für Berufsbildung und Technologie.

Bebchuk, L. and Y. Grinstein (2005), 'The growth of executive pay', Oxford Review of Economic Policy, Summer; 21(2), 283-303.

Beicht, U., G. Walden and H. Herget (2004), Kosten und Nutzen der betrieblichen Berufsausbildung in Deutschland. Bonn: BIBB.

Bellmann, L. and F. Janik (2007), 'To recruit skilled workers or train one's own? Vocational training in the face of uncertainty as to the rate of retention of trainees on completion of training', Zeitschrift für Arbeitsmarktforschung, 2-3, 205-220.

Ben Otham, H. and D. Zeghal (2006), 'A study of earnings management motives in the Anglo-American and Euro-Continental accounting models: the Canadian and French cases', International Journal of Accounting, 41, 406-35.

Benedict, A. and B. Elliott (2008), Financial Accounting: an Introduction. Harlow: Pearson Education.

Bens, D., V. Nagar, D.J. Skinner and M.H.F. Wong (2003), 'Employee stock options, EPS dilution and stock repurchases', Journal of Accounting and Economics, 36, 51-90.

Bergstresser, D. and T. Philippon (2006), 'CEO incentives and earnings management', Journal of Financial Economics, 80, 511-29.

Berle, A.A. and G.C. Means (1932), The Modern Corporation and Private Property. New York: Macmillan.

Black, B., H. Gospel and A. Pendleton (2007), 'Finance, corporate governance and the employment relationship', Industrial Relations, 46(3), 643-50.

Bloom, N. and J. van Reenen (2007), 'Measuring and explaining management practices across firms and countries', Quarterly Journal of Economics, 72(4), $1351-1408$.

Burns, N. and S. Kedia (2006), 'The impact of performance-based compensation on misreporting', Journal of Financial Economics, 79, 35-67.

Chan, S.H., J.D. Martin and J.W. Kesinger (1990), 'Corporate Research and Development expenditures and share value', Journal of Financial Economics, 26(2), 255-76. 
Cheffins, B.R. and S.A. Bank (2009), 'Is Berle and Means really a myth?', Business History Review, 83, 443-74.

Chen, S.K., B.-X. Lin, Y. Wang and L. Wu (2010), 'The frequency and magnitude of earnings management: time series and multithreshold comparisons', International Review of Economics and Finance, forthcoming.

Chung, R. M. Firth and J.-B. Kim (2002), 'Institutional monitoring and opportunistic earnings management', Journal of Corporate Finance, 8, 29-48.

Coffee, J.C. (2005), 'A theory of corporate scandals: why the US and Europe differ', Oxford Review of Economic Policy, 21(2), 198-211.

De Jong, Henk W. (1997), 'The governance structure and performance of large European corporations', Journal of Management and Governance, 1, 5-27.

Dechow, P. and R. Sloan (1991), 'Executive incentives and the horizon problem', Journal of Accounting and Economics, 14(1), 51-89.

Denis, D.J., P. Hanouna and A. Sarin (2006), 'Is there a dark side to incentive compensation?', Journal of Corporate Finance, 12, 467-88.

DIUS (2008), World-class Apprenticeships: Unlocking Talent, Building Skills for All. London: Department for Innovation, Universities and Skills.

DTI (2003), Accounting for People: Report of the Task Force on Human Capital Management. London: Department of Trade and Industry.

Enriques, L. and P. Volpin (2007), 'Corporate governance reforms in continental Europe', Journal of Economic Perspectives, 21(1), 117-40.

Faccio, M. and L.H.P. Lang (2002), 'The ultimate ownership of Western European corporations', Journal of Financial Economics, 65(3), 365-95.

FBD (2006), Public Takeovers in Europe. London: Freshfields Bruckhaus Deringer.

FBD (2009), Public Takeovers in Germany. Frankfurt: Freshfields Bruckhaus Deringer.

Ferrarini, G. and N. Moloney (2005), 'Executive remuneration in the UE: the context for reform', Oxford Review of Economic Policy, 21(2), 304-23.

Ferrarini, G., N. Moloney and C. Vespro (2003), 'Executive remuneration in the EU: comparative law and practice', ECGI Law Working Paper 09/2003. Brussels: European Corporate Governa nce Institute.

Franz, W. and D. Soskice (1995), 'The German apprenticeship system', in F. Buttler, W. Franz, R. Schettkat and D. Soskice (eds), Institutional Frameworks and Labour Market Performance. London: Routledge.

Fudenberg, K. and J. Tirole (1995), A theory of income and dividend smoothing based on incumbency rents', Journal of Political Economy, 103, 75-93.

Gospel, H. and A. Pendleton (2005), 'Corporate governance and labour management: an international comparison' in H. Gospel and A. Pendleton (eds), Corporate Governance and Labour Management: an International Comparison. Oxford: OUP.

Graham, J.R., C.R. Harvey, S. Rajgopal (2005), 'The economic implications of corporate financial reporting', Journal of Accounting and Economics, 40, 3-73. 
Green, J.P., A.W. Stark and H.M. Thomas (1996). 'UK evidence of the market valuation of research and development expenditures'. Journal of Business Finance \& Accounting. 23 (2), 191-216.

Grinyer, J., A. Russell and D. Collison (1998), 'Evidence of managerial short-termism in the UK', British Journal of Management, 9 (1), 13-22.

Guidry, F., A.J. Leone and S. Rock (1999), 'Earnings-based bonus plans and earnings management by business-unit managers', Journal of Accounting and Economics, 26, 113-42.

Hall, P. and D. Soskice (eds), Varieties of Capitalism. Oxford: OUP.

Hannah, L. (2007), 'The divorce of ownership from control from 1900: recalibrating imagined global historical trends', Business History, 49, 404-23.

Healy, P.M. (1985), 'The effect of bonus schemes on accounting decisions', Journal of Accounting and Economics, 7, 85-107.

Healy, P.M. and J.M Wahlen (1999), 'A review of the earnings management literature and its implications for standards setting', Accounting Horizons, 13, 365-83.

Hogarth, T. and T. Hasluck (2003), Net Cost of Modern Apprenticeship Training to Employers. Research Report 418. London: Department for Education and Skills.

Höpner, M. (2003), Wer beherrscht die Unternehmen? Shareholder Value, Managerherrschaft und Mitbestimmung in Deutschland. Frankfurt: Campus.

Höpner, M. (2005), 'What connects industrial relations and corporate governance? Explaining institutional complementarity', Socio-Economic Review, 3, 331-58.

Höpner, M. and G. Jackson (2006), 'Revisiting the Mannesmann takeover: how markets for corporate control emerge', European Management Review, 3(3), $142-55$.

Jacoby, S. (2009), 'Finance and labour: perspectives on risk, inequality and democracy', in C. Brown, B. Eichengreen and M. Reich (eds), Labour in the Era of Globalization. Cambridge: CUP.

Jensen, M. and K. Murphy (2004), 'Remuneration: where we've been, how we got there, what the problems are, and how to fix them', Finance Working Paper 44/2004. Brussels: European Corporate Governance Institute.

Konzelmann, S., N. Conway, L. Trenberth and F. Wilkinson (2006), 'Corporate governance and human resource management', British Journal of Industrial Relations, 44(3), 541-67.

La Porta, R., F. Lopez-de-Silanes and A. Shleifer (1999), 'Corporate ownership around the world', Journal of Finance, 54(2), 471-517.

Lambert, C., D. Gericke, D. Grünblatt and G. Brei (2010), 'Switzerland', in C. Cogut (ed.), Mergers and Acquisitions in 61 Jurisdictions Worldwide. London: Law Business Research Ltd.

Lazonick, W. and M. O'Sullivan (2002), Corporate Governance and Sustainable Prosperity. Basingstoke: Palgrave.

Leuz, C. and J. Wüstermann (2004), 'The role of accounting in the German financial system', in J.P. Krahnen and R.H. Schmidt (eds), The German Financial System. Oxford: OUP. 
Leuz, C., D. Nanda and P.D. Wysocki (2003), 'Earnings management and investor protection: an international comparison', Journal of Financial Economics, 69(3), 505-27.

Lewis, P. and P. Ryan (2009), 'The role of external inspection in the public services: the case of the UK training market', Public Administration, 87(4), 791-817.

Lewis, P., H. Gospel and P. Ryan (2008), 'A hard sell? The prospects for apprenticeship in British retailing', Human Resource Management Journal, 18(1), 3-19.

Mason, G. and K. Wagner (2005), 'Restructuring of automotive supply-chains: the role of workforce skills in Germany and Britain', International Journal of Automotive Technology and Management, 5(4), 387 seq.

Mayer, C. (1997), 'Corporate governance, competition and performance', Journal of Law and Society, 24, 152-76.

Miles, D. (1995), 'Testing for short-termism in the UK stock market: a reply'. Economic Journal, 105, 1224-1227.

Miller, M.H. (1997), 'Is American corporate governance fatally flawed?', in D. Chew (ed.), Studies in International Corporate Finance and Governance Systems. Oxford: OUP.

Monks, R. and N. Minow (2008), Corporate Governance, $4^{\text {th }}$ ed.. Chichester: Wiley.

Morck, R., D. Wolfenzon and B. Yeung (2005), 'Corporate governance, economic entrenchment and growth', Journal of Economic Literature, 43(3), 655-720.

Mühlemann, S. S.C. Wolter, M. Fuhrer and A. Wüest (2007), Lehrlingsausbildung ökonomisch betrachtet. Chur: Rüegger Verlag.

Murphy, K.J. (1999), 'Executive compensation', in O. Ashenfelter and D. Card (eds), Handbook of Labour Economics, vol. 3B. Amsterdam: Elsevier.

Noack, U. and D.A. Zetzsche (2005), 'Corporate reform in Germany: the second decade', European Business Law Review, 16(5), 1033-64.

Nowak, E. (2004), 'Investor protection and capital market regulation in Germany', in J.P. Krahnen and R.H. Schmidt (eds), The German Financial System. Oxford: OUP.

PWC (2003), 'Human capital management practices outside the UK'. London: Pricewaterhousecoopers.

Roberts, H. (2007), 'Knowledge resources and management activity', in T. Hopper, D. Northcott and R. Scapens (eds), Issues in Management Accounting, $3^{\text {rd }}$ ed. Harlow: Pearson Education.

Roychowdury, S. (2006), 'Earnings management through real activities manipulation', Journal of Accounting and Economics, 42, 335-70.

Ryan, P. (2010), 'Training markets', in P. Petersen, E. Baker, and B. McGaw (eds), International Encyclopaedia of Education, vol 8, pp. 496-502. Oxford: Elsevier.

Ryan, P. and L. Unwin (2001), 'Apprenticeship in the British "training market",' National Institute Economic Review, 178, 70-85. 
Ryan, P., H. Gospel and P. Lewis (2007), 'Large employers and apprenticeship training in Britain', British Journal of Industrial Relations, March, 45(1), 127 53.

Ryan, P., K. Wagner, S. Teuber and U. Backes-Gellner (2010), Financial Aspects of Apprenticeship Training in Germany, Great Britain and Switzerland. Report to Hans-Böckler Stiftung.

Solomon, Jill (2010), Corporate Governance and Accountability $3^{\text {rd }}$ ed. Chichester: Wiley.

Steedman, H. and K. Wagner (2003), ICT Skills in the UK and Germany: how Companies Adapt and React, Centre for Economic Performance, London School of Economics.

Stein, J.C. (1989), 'Efficient capital markets, inefficient firms: a model of myopic corporate behaviour', Quarterly Journal of Economics, 104(4), 655-69.

Stevens, M. (1994), 'A theoretical model of on-the-job training', Oxford Economic Papers, 46(4), 537-562.

Streeck, W. (2009), Re-Forming Capitalism: Institutional Change in the German Political Economy. Oxford: OUP.

Streeck, W. and K. Yamamura (2001), The Origins of Nonliberal Capitalism. Cornell NY: Cornell University Press.

Ullman, A. and G. Deakin (2005), Apprentice Pay: a Survey of Earnings by Sector. Research Report 674, Department for Education and Skills. London: HMSO.

Vitols, S. (2001), 'Varieties of corporate governance: comparing Germany and the UK', in P. Hall and D. Soskice (eds), Varieties of Capitalism. Oxford: OUP. 


\section{Appendix 1. Research methods and establishment attributes}

Our engineering cases are chosen from national listings of British and Swiss establishments by four digit Standard Industrial Classification (SIC) code, as compiled by Dun and Bradstreet. That source shows for pumps, turbines and compressors significant numbers of medium-sized establishments (broadly speaking, between 100 and 700 employees) in both countries. We identified comparable German producers from various German sources, including the directory Wer Liefert Was?, concentrating the German search on four regions: Berlin, the Ruhr, BadenWürttemberg, and Hamburg. Although we did not seek specifically to include establishments located in the former DDR, two of the Berlin-based retailing establishments are located there. The inclusion of additional subsectors in both engineering and retailing resulted from the need to include German companies that are not covered by collective bargaining (ohne Tarifbindung), none of which could be located in the core subsectors. Although we did not specifically seek only establishments that provide apprenticeship training, our sample comprises almost entirely those that do - with important exception of British retailing, in which none of the stores or divisions in our sample operates an Apprenticeship programme.

Table A1 shows the distribution of interviewed establishments across subsectors. These sectors account for around 0.5 per cent (engineering) and between 2.8 and 5.4 per cent (retailing, in Switzerland and Britain respectively) of total employment in the three countries. The data refer in engineering mostly to middle sized establishments owned by large companies, and in retailing mostly to groups of small to medium sized stores, most of them part of large national retail chains (Table A2).

Eighteen of the establishments are the subsidiary of a parent company shared with one or more establishments in the other countries. Most are simple pairs, whether German/British or German/Swiss; one group involves four establishments in a single large company, spread across the three countries. Most of the paired establishments are in engineering (Table A3). 
Table A1. Number of participating establishments by sector

\begin{tabular}{llccccc}
\hline Sector & Subsector & SIC & \multirow{2}{*}{ GB } & \multirow{2}{*}{ DE } & CH & All \\
\hline Engineering & Pumps and pumping equipment & 3561 & 4 & 4 & 4 & 12 \\
& Turbines and turbine generator sets & 3511 & 1 & 2 & 2 & 5 \\
& Air and gas compressors & 3563 & 0 & 0 & 1 & 1 \\
& Aircraft engines and parts & 3724 & 1 & 0 & 0 & 1 \\
& Electronic components, n.e.c. & 3679 & 3 & 2 & 2 & 7 \\
& All engineering subsectors & & 9 & 8 & 9 & 26 \\
& & & & & & \\
Retailing & Department stores $^{\text {Grocery stores }}{ }^{\text {a }}$ & 5311 & 4 & 2 & 3 & 9 \\
& Shoe stores $^{\text {a }}$ & 5411 & 3 & 3 & 2 & 8 \\
& Furniture stores $^{\text {a }}$ & 5661 & 1 & 2 & 2 & 5 \\
& Radio, TV and electronics stores $^{\text {a }}$ & 5712 & 1 & 1 & 1 & 3 \\
& All retailing subsectors & 5731 & 1 & 2 & 2 & 5 \\
Both & & & 10 & 10 & 10 & 30 \\
& & & & & & \\
& & & 19 & 18 & 19 & 56 \\
\hline
\end{tabular}

Note:

a. Groups of stores, typically at regional (division) or national (company) level

Table A2. Employment and training in participating establishments

\begin{tabular}{llcccccc}
\hline & & \multicolumn{3}{c}{ Engineering } & \multicolumn{3}{c}{ Retailing } \\
& & GB & DE & CH & GB & DE & CH \\
\hline Employment & Median & 377 & 500 & 308 & 1334 & 3348 & 333 \\
& Mean & 1739 & 2959 & 288 & 37650 & 12957 & 2406 \\
& Share (\%) & 4.2 & 10.5 & 11.2 & 45.7 & 42.4 & 42.8 \\
Apprentices & Mean & 27 & 68 & 39 & $0^{\mathrm{b}}$ & 598 & 155 \\
\hline
\end{tabular}

Note: participating establishments comprise single ones in engineering and, in retailing, both single establishments (department stores) and groups of establishments (divisions, regions and companies).

a. Share of total employment in parent company or group

b. Sales trainees only (no Apprentices)

Table A3. Establishments with the same multi-national parent company

\begin{tabular}{lcccc}
\hline & GB/DE & DE/CH & GB/DE/CH & All \\
\hline Engineering & 2 & 3 & 1 & 6 \\
Retailing & 1 & 1 & 0 & 2 \\
Number of establishments & 6 & 8 & 4 & 18 \\
\hline
\end{tabular}


Table A4. Participating companies by detailed ownership category, sector and country

\begin{tabular}{lcccccccc}
\hline & \multicolumn{3}{c}{ Engineering } & \multicolumn{3}{c}{ Retailing } & \multicolumn{2}{c}{ All } \\
& GB & DE & CH & GB & DE & CH & \\
\hline Listed, dispersed ownership & 5 & 1 & 3 & 3 & 0 & 0 & 12 \\
Listed, blockholder(s) & 2 & 4 & 2 & 0 & 3 & 2 & 13 \\
Unlisted: family, foundation, coop & 1 & 2 & 4 & 5 & 7 & 7 & 26 \\
Unlisted: investor group & 1 & 1 & 0 & 2 & 0 & 1 & 5 \\
All & 9 & 8 & 9 & 10 & 10 & 10 & 56 \\
\hline
\end{tabular}

Companies that declined to participate were replaced by comparable ones until a full set of interviews had been obtained. The participation rate among companies approached was 79 per cent in Switzerland, 60 per cent in Germany, and 43 per cent in England. It is likely that our sample is implicitly selected towards (i) larger parent companies and (ii) bigger and better apprentice training programmes. Selection bias is least troubling for Swiss engineering, in which the response rate is high and sample size is close to population size.

Most interviews were conducted by two or three members of the research team; a handful, by one or by all four. A team member based in the establishment's own country was present in all cases. The interviews, which lasted around 1.5 hours on average, were conducted around a detailed questionnaire, the content of whose English and German language versions was close. Some interviews in Germany and Switzerland were conducted in English. A short (two page) statistically-oriented excerpt was sent to interviewees to complete in advance. In a few cases some key data could not be obtained. 


\section{Appendix 2. Distribution of company types in national data}

Table A5. Distribution of companies by ownership and country

Share of all companies in category

\begin{tabular}{|c|c|c|c|c|c|c|c|}
\hline \multicolumn{8}{|c|}{ Corporate form } \\
\hline & & $\begin{array}{c}\text { AG/ } \\
\text { PLC }^{\mathbf{a}}\end{array}$ & $\underset{\text { Ltd }^{\mathbf{b}}}{\mathbf{G m b H} /}$ & $\begin{array}{c}\text { Co- } \\
\text { operative }^{c}\end{array}$ & Other $^{d}$ & All & $\begin{array}{c}\text { No. of } \\
\text { companies }\end{array}$ \\
\hline \multirow[t]{3}{*}{ All sectors } & $\overline{\text { GB }}$ & 0.1 & 93.1 & 4.0 & 2.9 & 100.0 & $2,444,687$ \\
\hline & DE & 0.2 & 14.6 & 0.2 & 85.0 & 100.0 & $3,140,509$ \\
\hline & CH & 27.8 & 15.0 & 0.7 & 56.5 & 100.0 & 298,722 \\
\hline \multirow[t]{3}{*}{ Engineering } & $\mathbf{G B}$ & 1.0 & 98.7 & 0.1 & 0.2 & 100.0 & 45,485 \\
\hline & DE & 0.8 & 42.3 & 0.0 & 56.9 & 100.0 & 24,738 \\
\hline & $\mathbf{C H}$ & 56.8 & 12.5 & 0.0 & 30.7 & 100.0 & 3,406 \\
\hline \multirow[t]{3}{*}{ Retailing } & $\mathbf{G B}$ & 0.3 & 99.0 & 0.5 & 0.2 & 100.0 & 190,634 \\
\hline & DE & 0.1 & 15.8 & 0.1 & 83.9 & 100.0 & 699,980 \\
\hline & CH & 30.9 & 16.1 & 0.8 & 52.2 & 100.0 & 68,830 \\
\hline
\end{tabular}

Sources. UK. FAME dataset (BvDEP 2009). DE: Statistisches Bundesamt (2007), Umsatzsteuerstatistik 2007. Steuerpflichtige und deren Lieferungen und Leistungen 2007 nach Rechtsformen, VID/37331100. CH: Bundesamt für Statistik (2007), Marktwirtschaftliche Unternehmen nach Wirtschaftsabteilungen und Rechtsform, 2005

Notes.

a. Public company, listed or unlisted; includes Aktiengesellschaft (DE, CH) and PLC (UK)

b. Private company; includes Gesellschaft mit beschränkter Haftung (DE, CH) and Limited company (UK)

c. Includes in UK Industrial/Provident Associations and Companies Limited by Guarantee

d. In DE, Einzelgesellschaften, Kommanditgesellschaften, Betrieb gewerblicher Art. von Körperschaft des öffentlichen Rechts, sonstige Rechtsform; in $\mathrm{CH}$, Einzelfirmen, Kollektivgesellschaften, Kommanditgesellschaften, Andere; in UK, unlimited liability companies and partnerships.

Table A6. Distribution of number of businesses and turnover by business type and sector, private non-farm business, Switzerland, 2007 (\%)

\section{Machinery \\ Manufacture \\ (DK29)}

\begin{tabular}{llrrrrrr}
\hline & & Number & Turnover & Number & Turnover & Number & Turnover \\
\hline AG & PLC & 0.8 & 17.0 & 0.1 & 12.6 & 0.2 & 19.1 \\
GmbH & Limited & 43.4 & 44.1 & 10.3 & 18.3 & 14.6 & 35.7 \\
Komanditgesellschaft & $\begin{array}{c}\text { Company } \\
\text { Partnership }\end{array}$ & 13.5 & 31.8 & 2.7 & 35.4 & 4.2 & 23.4 \\
Genossenschaft & Cooperative & n.a. & n.a. & n.a. & n.a. & 0.2 & 1.1 \\
Einzelunternehmen & Sole trader & 36.4 & 3.0 & 80.3 & 25.5 & 70.3 & 10.2 \\
Andere & Other & 5.8 & 4.1 & 6.6 & 8.2 & 10.5 & 10.5 \\
\hline All & & 100.0 & 100.0 & 100.0 & 100.0 & 100.0 & 100.0 \\
\hline
\end{tabular}

Totals

Source: Statistiches Bundesamt, Umsatzsteuerstatistik (VID/37331 100)

Notes:

Businesses with tax liability and turnover of at least $€ 17,500$ p.a.; turnover measured after sales taxes n.a: data not released

a. Limited partnerships only 